\title{
KAJIAN RISET MONODISIPLINER DAN INTERDISIPLINER DALAM PENDIDIKAN ISLAM MENGHADAPI ISU NASIONAL DAN GLOBAL: Studi Kasus terhadap Isu Covid-19
}

\author{
Ni'mawati, Uus Ruswandi dan Mohamad Erihadiana \\ Dosen Program Doktoral Ilmu Pendidikan Islam Universitas Islam \\ Sunan Gunung Djati Bandung \\ nimawatiihwanudin@gmail.com
}

\begin{abstract}
Abstrak
Penelitian ini dilatarbelakangi oleh terjadinya diskursus di tengah-tengah masyarakat dewasa ini mengenai pandemi Covid-19. Sebagian orang menganggap ringan wabah ini dengan mengatakan bahwa kematian sudah ditentukan oleh Allah Swt. Sebagian yang lain menganggap serius wabah ini dan berupaya menghindari serta mencari strategi pencegahan dan solusinya. Bertitik tolak dari uraian tersebut penting untuk meneliti kajian monodisipliner dan interdisipliner dalam pendidikan islam menghadapi isu nasioal dan global dengan melakukan studi kasus terhadap isu covid-19. Tujuan dari penelitian ini adalah untuk menganalisis pandemi Covid-19 dengan pendekatan monodisipliner Pendidikan Agama Islam (PAI), intradisipliner rumpun ilmu PAI, interdisipliner antara PAI dan rumpun ilmu PAI dengan disiplin ilmu-ilmu lainnya yang berkaitan dengan objek bahasan ini. Penelitian ini menggunakan metode analisis deskriptif pendekatan kualitatif dengan sumber data kepustakaan. Hasil penelitian ini adalah: pertama, dengan pendekatan monodisipliner PAI pandemi Covid-19 adalah ciptaan Allah Swt yang harus disikapi dengan tepat, kedua, dengan pendekatan transdisipliner melalui disiplin ilmu kalam, fikih, hadis dan sejarah peradaban islam bahwa ditemukan sikap dan penanganan Covid-19 dalam praktis Rasulullah dan sahabat juga pemahamn para ulama, dan ketiga, dengan pendekatan multidisipliner bahwa Covid-19 adalah sebagai berikut, menurut ahli virologi penyebab dari wabah ini adalah coronavirus jenis baru yang disebut dengan novel coronavirus 2019 (2019-n CoV). Menurut farmakologi penyembuhannya dengan obat virus. Menurut kesehatan harus menjaga jarak dengan penderita dan harus menjaga kebersihan. Adapun menurut ahli ekonomi dan pemerintahan pandemi ini berdampak pada sektor ekonomi maka tidak dapat dilaksanakan lockdown.
\end{abstract}

Kata Kunci: monodisipliner; interdisipliner; PAI; dan Covid-19 


\section{A. Pendahuluan}

Arus perubahan kehidupan dunia sangat cepat dalam segala bidang. Semakin terinterkoneksikannya jaringan keilmuan, kehidupan sosial, budaya, ekonomi, dan agama antar bangsa di dunia, menuntut manusia untuk mampu berpikir kompleks, mampu menjadi pribadi adaptif dalam upaya memecahkan masalah-masalah yang menjadi isu global seperti Korupsi, penegakan hukum, human traficing, bias gender, perubahan iklim, kelangkaan energi, kerusakan lingkungan, pertumbuhan penduduk, ketahanan pangan, radikalisme agama, terorisme dan wabah corona (Civid-19) yang sedang marak sekarang ini.

Kehidupan manusia bersifat kompleks dan multi-dimensi, dalam berbagai aspek dan levelnya. Keberadaan beragam disiplin ilmu, baik ilmu agama, ilmu-ilmu alam maupun humaniora, hakikatnya adalah upaya manusia untuk memahami kompleksitas dimensi-dimensi hidup manusia tersebut. Setiap disiplin ilmu mencoba menyelami dimensi tertentu dari hidup manusia. ${ }^{1}$

Permasalahan kompleks yang melekat kuat dalam kehidupan manusia tidak dapat lagi diselesaikan dengan pendekatan monodisipliner. Saat ini kita memerlukan pendekatan riset yang bercorak interdisipliner. Riset yang bercorak interdisipliner melibatkan pengetahuan yang dihasilkan dengan cara mengombinasikan beberapa elemen dari berbagai disiplin ilmu, termasuk pengetahuan yang nondisipliner, atau dari pemangku kepentingan yang relevan dan kemudian menciptakan ilmu pengetahuan baru yang lebih komprehensif dan sintesis yang menjangkau banyak bidang. Metode seperti itu, isu-isu yang kompleks sekalipun dapat dibicarakan secara tepat dan lebih memuaskan dalam ruang intelektual baru serta dapat mempromosikan inovasi dan penyuburan silang ilmu pengetahuan.

Penelitian ini menggunakan metode analisis deskriptif pendekatan kualitatif dengan sumber data kepustakaan. Riset monodisipliner dan interdisipliner ini tepat digunakan dalam menghadapi isu saat ini baik nasional maupun global. Oleh karena itu penting bagi penulis untuk melakukan kajian dengan pendekatan multidisipliner mengenai kasus pandemi Covid-19.

${ }^{1}$ Tim Pokja Akademik, Kerangka Dasar Keilmuan dan Pengembangan Kurikulum Universitas Islam Negeri (UIN) Sunan Kalijaga Yogyakarta, (Yogyakarta: UIN Press, 2006), 15. 


\section{B. Pendekatan Monodisipliner}

Pendekatan dalam suatu ilmu dapat ditinjau melalui dua tipe yaitu monodisipliner dan interdisipliner. Pendekatan monodisipliner adalah pendekatan dengan suatu ilmu dengan satu sudut pandang. Pendekatan monodisipliner memiliki ciri mono (satu ilmu).

Terdapat dua watak dasar dalam perkembangan ilmuilmu modern. Pertama, bangunan ontologis, epistemologis, teoretis, dan metodologis ilmu-ilmu (spesialistis-partikular) kealamanan, ilmu-ilmu sosial, dan humaniora. Kedua, masingmasing disiplin ilmu terdapat pemisah dengan mengabaikan keberadaan ilmu-ilmu lain atau kerja sama ilmu-ilmu; kerja sama ilmu-ilmu dan gabung-ilmu-ilmu benar-benar dianggap "cinta terlarang". ${ }^{2}$

Berikutnya, Saryono menjelaskan fajar era monodisipliner disertai dengan berkembangnya dan atau menguat-menonjolnya (sebutlah) 'ideologi' kemonodisiplineran dalam ilmu-ilmu (monodisiplinerisme) pada umumnya, ilmu-ilmu alam atau ilmu analitis, ilmu-ilmu sosial atau ilmu-ilmu emansipatoris, ilmu-imu humaniora atau ilmu hermeneutis. Monodisiplinerisme mewawasi, melandasi, dan menggerakkan segenap ilmu-ilmu dalam bekerja. Kerja ilmu dan temuan teori dikendalikan oleh monodisiplinerisme semata. Dalam bekerja ini, 'ideologi' monodisiplinerisme ini meyakini empat hal.

Pertama, ilmu-ilmu apapun harus mengejar tujuan dan kepentingan tertentu yang melekat (inheren) dalam dirinya sendiri (internal), bukan mengejar suatu tujuan dan kepentingan di luar dirinya (eksternal), misalnya kepentingan kemanusiaan; kepentingan kemanusiaan merupakan soal aksiologi ilmu yang bukan urusan langsung ilmu.

Kedua, ilmu-ilmu apapun harus bekerja dengan asas-asas disipliner yang ketat dan pasti yang dimilikinya dan dalam batasbatas cakupan yang telah ditetapkan, bukan asas ketuntasan masalah tertentu yang harus dikajinya dan kememandaian jawaban atas masalah-masalah keilmuan.

\footnotetext{
${ }^{2}$ http://library.um.ac.id, diunduh 18 Maret 2020.
} 
Ketiga, ilmu-ilmu apapun perlu bekerja dengan satu teori dan metodologi yang sesuai dengan tujuan dan kepentingan monodisipliner, tidak perlu atau tidak boleh bekerja dengan piranti-piranti teoretis dan metodologis dalam suatu kajian ilmiah disebut dengan nama eklektisisme, bukan disebut multidisiplineritas atau interdisipliner.

Terakhir, keempat, ilmu-ilmu apapun wajib mengusung objektivitas-empiris yang notabene positivistis sebagai pilar sekaligus tolok ukur (tunggal?) aktivitas penelitian ilmiah termasuk ilmu-ilmu sosial dan ilmu kemanusiaan; tidak ayal ilmu-ilmu alam, sosial, dan kemanusiaan (sama-sama dimatikan). Entitas, watak, dan sifat objek ilmu-ilmu sosial atau ilmu emansipatoris dan apalagi ilmu-ilmu kemanusiaan atau ilmu hermeneutis yang sesungguhnya amat hidup, cair-lunak, dan mudah bergerak pun harus dimatikan suspaya memperoleh status keilmiahan yang kokoh.

\section{Pendekatan Interdisipliner}

Pendekatan dengan banyak ilmu lazim disebut pendekatan interdisipliner/multidisipliner Jika dirinci berdasarkan karakteristiknya, pendekatan interdisipliner ini dapat dibagi kedalam 4 jenis pendekatan, yaitu: pendekatan interdisipliner, pendekatan multidisipliner, pendekatan transdisipliner, dan pendekatan krosdisipliner.

Interdisipliner (interdisciplinary) adalah interaksi intensif antar satu atau lebih disiplin, baik yang langsung berhubungan maupun yang tidak, melalui program-program penelitian, dengan tujuan melakukan integrasi konsep, metode, dan analisis. Multidisipliner multidisciplinay) adalah penggabungan beberapa disiplin untuk bersama-sama mengatasi masalah tertentu. Transdisipliner (transdisciplinarity) adalah upaya mengembangkan sebuah teori atau aksioma baru dengan membangun kaitan dan keterhubungan antar berbagai disiplin. ${ }^{3}$

3 Prentice, A.E, "Introduction" dalam Information Science-The Interdisciplinary Context. (ed. J. M. Pemberton dan A.E. Prentice), (New York: Neal-Schuman Publishers, 1990). 
Pendekatan interdisipliner (interdisciplinary approach) ialah pendekatan dalam pemecahan suatu masalah dengan menggunakan tinjauan berbagai sudut pandang ilmu serumpun yang relevan secara terpadu. Yang dimaksud dengan ilmu serumpun ialah ilmu-ilmu yang berada dalam rumpun ilmu tertentu, yaitu rumpun Ilmu-Ilmu Kealaman (IIK), rumpun Ilmu Ilmu Sosial (IIS), atau rumpun Ilmu Ilmu Budaya (IIB) sebagai alternatif. Ilmu yang relevan maksudnya ilmu- ilmu yang cocok digunakan dalam pemecahan suatu masalah. Adapun istilah terpadu, yang dimaksud yaitu ilmu ilmu yang digunakan dalam pemecahan suatu masalah melalui pendekatan ini terjalin satu sama lain secara tersirat (implicit) merupakan suatu kebulatan atau kesatuan pembahasan atau uraian termasuk dalam setiap subsub uraiannya kalau pembahasan atau uraian itu terdiri atas subsub uraian. Ciri pokok atau kata kunci dari pendekatan interdisipliner ini adalah inter (terpadu antarilmu dalam rumpun ilmu yang sama) atau terpadunya itu.

Pendekatan multidisipliner (multidisciplinary approach) ialah pendekatan dalam pemecahan suatu masalah dengan menggunakan tinjauan berbagai sudut pandang banyak ilmu yang relevan. Ilmu ilmu yang relevan digunakan bisa dalam rumpun Ilmu Ilmu Kealaman (IIK), rumpun Ilmu Ilmu Sosial (IIS), atau rumpun Ilmu Ilmu Humaniora (IIH) secara alternatif. Penggunaan ilmu-ilmu dalam pemecahan suatu masalah melalui pendekatan ini dengan tegas tersurat dikemukakan dalam suatu pembahasan atau uraian termasuk dalam setiap urain sub-sub uraiannya bila pembahasan atau uraian itu terdiri atas sub-sub uraian, disertai kontribusinya masing masing secara tegas bagi pencarian jalan keluar dari masalah yang dihadapi. Ciri pokok atau kata kunci dari pendekatan multidisipliner ini adalah multi (banyak ilmu dalam rumpun ilmu yang sama).

Pendekatan transdisipliner (transdisciplinary approach) ialah pendekatan dalam pemecahan suatu masalah dengan menggunakan tinjauan ilmu yang relatif dikuasai dan relevan dengan masalah yang akan dipecahkan tetapi berada di luar keahlian sebagai hasil pendidikan formal (formal education) dari orang yang memecahkan masalah tersebut. Ilmu yang berada di luar keahlian yang akan digunakan oleh seseorang itu bisa satu atau lebih ilmu. 
Namun, biasanya untuk keperluan kedalaman pembahasan orang itu hanya menggunakan satu ilmu saja di luar keahliannya itu. Ilmu yang relevan digunakan bisa dalam rumpun Ilmu Ilmu Kealaman (IIK), rumpun Ilmu Ilmu sosial (IIS), atau rumpun Ilmu Ilmu Humaniora (IIH) sebagai alternatif. Penggunaan ilmu atau ilmu-ilmu dalam pemecahan suatu masalah melalui pendekatan ini bisa secara tersirat atau tersurat, tetapi akan lebih baik dan biasasnya memang tersurat.

Hal itu dilakukan untuk menunjukkan pertanggungjawaban keilmuan orang tersebut. Pendekatan ini dahulu kurang diterima karena dianggap melanggar etika keilmuan oleh para ahli ilmu terutama oleh mereka yang ilmunya digunakan oleh orang yang bukan ahlinya itu. Akan tetapi, dewasa ini hal itu dimungkinkan karena pesatnya perkembangan ilmu pengetahuan, teknologi, dan seni (ipteks) lagi pula kompleksnya permasalahan yang pada umumnya sulit dipecahkan oleh hanya dengan pendekatan satu ilmu (pendekatan monodisipliner) saja. Bahkan pada saat yang sama diterima baik oleh kalangan ilmuan termasuk oleh ilmuan ahlinya asalkan dalam pemecahan suatu masalah itu menunjukkan kualitas dan kebenaran yang memadai.

Dengan demikian, seseorang yang menggunakan pendekatan transdisipliner harus pula dipenuhi syarat sebagai berikut: a) menggunakan ilmu di luar ilmu keahlian utamanya, biasanya dalam memecahkan suatu masalah menggunakan satu ilmu di luar ilmu keahliannya itu; b) ilmu yang digunakan berada dalam rumpun ilmu yang sama dengan ilmu keahlian utamanya; c) memahami dengan baik ilmu yang digunakan di luar keahlian ilmu utamanya itu; d) menunjukkan hasil dengan kualitas dan kebenaran yang memadai. Ciri pokok pendekatan transdisipliner adalah trans (lintas ilmu dalam rumpun ilmu yang sama) atau melintasnya.

Selain penjelasan di atas, Secara definitif interdisiplin menyarankan penelitian dengan melibatkan dua bidang ilmu atau lebih. Dikaitkan dengan jangkauan, model, dan batasan- batasan lain yang ditentukan dalam analisis, maka jelas interdisiplin termasuk penelitian ekstrinsik, sebagai makro sastra. Istilah lain yang juga dikenal, di antaranya: multidisiplin, krosdisiplin, transdisiplin, antardisiplin, dan lintas disiplin. 
Multidisiplin menyarankan bahwa sejumlah ilmu, lebih dari dua ilmu yang berbeda digunakan untuk menganalisis masalah yang sama. Sebagai disiplin baru multidisiplin menampilkan dua model penelitian, yaitu multidisiplin murni, setiap ilmu seolah-olah masih berdiri sendiri dengan teori dan metodenya masing- masing dan multidisiplin terapan, salah satu ilmu menduduki posisi dominan. Contoh kajian pertama dilakukan dalam penelitian kelompok, seperti proyek, di dalamnya masing-masing ilmu akan memisahkan diri sesudah tugas akhir selesai dilakukan, sedangkan kajian kedua berada dalam ikatan disiplin tertentu, seperti kajian budaya (cultural Studies).

Selanjutnya, menurut Ratna menyatakan interdisiplin, krosdisiplin, transdisiplin, antardisiplin, dan lintas disiplin, masing-masing terdiri atas dua ilmu. Perbedaannya, dalam dua pendekatan yang pertama kedua ilmu dimungkinkan lebur menjadi satu, seperti antropologi sastra, sosiologi sastra, dan psikologi sastra. Dalam bidang lain dikenal psikolinguistik, antropologi linguistik, agribisnis, agronomi, sosiatri, dan sebagainya. Sebaliknya dalam tiga pendekatan yang terakhir masing-masing ilmu masih berdiri sendiri. Seperti dalam multidisiplin, dalam proses penelitian salah satu di antaranya menduduki posisi dominan. Pada dasarnya interdisiplin dan krosdisiplin mulai dengan transdisiplin, antardisiplin, dan lintas disiplin. Perkembangannya dipicu dengan adanya keperluan manusia untuk memahami sekaligus menggunakan keseluruhan aspek kebudayaan demi keperluan manusia itu sendiri.

Ada dua pendapat mengenai kelahiran pendekatan interdisipliner. Ada sebagian ahli yang mengatakan bahwa konsep interdisipliner merupakan, yang berakar dari teori-teori, misalnya, teori Plato, Kant, Hegel, dan Aristoteles.

Sebagian ahli yang lain, mengatakan bahwa konsep interdisipliner ini merupakan fenomena abad kedua puluh dengan adanya pembaharuan dalam dunia pendidikan, penelitian terapan, dan kegiatan yang menyeberang dari batasan-batasan disiplin tertentu. Meskipun ide dasarnya dapat dikatakan tua, istilah interdisipliner itu baru muncul pada abad ke-20. 
Menurut Klein (1990), studi interdisipliner dilakukan pendidik, peneliti, dan banyak praktisi karena studi itu dapat menjawab situasi yang kompleks, menjawab permasalahan yang luas, meneliti hubungan antardisiplin, menjawab masalah yang ada di luar lingkup salah satu disiplin yang ada, dan mendapatkan keutuhan pengetahuan, baik dalam skala terbatas maupun luas.

Rintisan saling-silang dan kerja sama ilmu-ilmu dan metode-metode yang disertai perubahan filosofis tersebut mulai banyak atau marak dilakukan pada dasawarsa 1980-an. Gerakan saling-silang dan kerja sama ilmu-ilmu dan metode penelitian pun dimulai, kemudian berkembang cukup baik pada masa selanjutnya. Di sinilah dapat disaksikan munculnya gerak konvergensi dalam tradisi ilmu-ilmu modern, yaitu gerak perapatan, penggabungan, penyatuan, pemaduan, dan pengombinasian teori dan metodologi ilmu-ilmu yang beraneka ragam dan majemuk. Sebagai contoh, saling silang dan kerja sama ilmu biologi dan teknologi melahirkan bioteknologi, saling silang dan kerja sama antara antropologi dan psikologi menghasilkan antropologi psikologi. Hal ini menegaskan bahwa gerak konvergensi menjadikan disiplin-disiplin ilmu (yang spesialitis) dan metode-metode yang dulu terpisah-pisah (yang partikular) mulai bertemu dan menyatu lagi; dalam hal ini berbagai disiplin dan metode digunakan secara serempak dalam kegiatan keilmuan terutama kegiatan penelitian tanpa harus disebut eklektivisme, melainkan kombinasi, percampuran (mixing), dan penyematan (blending).

Misalnya, gerakan mengombinasikan atau memadukan fisika dengan pikiran mistisisme Timur sebagaimana terlihat dalam buku The Tao of Physics karya Fritjof Capra melahirkan Fisika Baru yang dipelopori oleh Gari Sukav. Pada awal tahun 1990-an juga mulai muncul dan berkembang pula gerakan memadukan atau meleburkan metodologi kualitatif dan kuantitatif-yang dahulu dilarang atau dianggap tidak mungkinsebagaimana tampak pada buku Mixing Method: Qualitative and Quantitative Research karya Julia Brannen (1993), Research Design: Qualitative and Quantitative Approach karya John W. Creswell (1997), dan Blending of Qualitative and Quantitative Research karya Amstrong (2003).

4 Sartono Kartodirdjo Pemikiran dan Perkembangan Historiografi Indonesia: Suatu Alternatif (Jakarta: Gramedia, 1982), 10. 
Pernah ada beberapa retasan kesadaran untuk menempatkan multidisiplin yang terdapat dalam payung humaniora dalam format interdisiplin. Untuk menyebut, di antaranya adalah, dalam konteks disiplin sejarah, yang mulai dirintis oleh salah seorang the founding father sejarah modern Indonesia, yakni Sartono Kartodirdjo yang mengungkapkan, bahwa perlu disadari sepenuhnya oleh sejarawan dewasa ini, bahwa suatu penulisan sejarah senantiasa dibayangi oleh subjektivitas kesempitan cakrawala mental, ikatan kultural dan zaman, serta konteks sosial, sehingga hanya suatu pikiran yang kritis saja dapat menjauhkannya subjektivitas itu. ${ }^{5}$ Karenanya, disiplin sejarah dalam perkembangannya harus bergeser, dari paradigma klasik-tradisional, yang kecenderungannya adalah 'ekslusif' dan asing terhadap kajian-kajian dari disiplin sosial budaya lainnya, ke arah yang lebih terbuka. Dengan mengintegrasikan pendekatan-pendekatan baru dalam ilmu-ilmu sosial, penyusunan sejarah diharapkan mampu mengungkapkan banyak persoalan dan objek-objek baru, serta dimensi-dimensi dari perubahan sosial dalam kehidupan secara penuh (the fullness of life.$^{6}$

\section{Pendidikan Islam}

Pendidikan Islam adalah usaha orang dewasa muslim yang bertakwa secara sadar mengarahkan dan membimbing pertumbuhan serta perkembangan fitrah (kemampuan dasar) anak didik melalui ajaran Islam ke arah titik maksimal pertumbuhan dan perkembangannya. ${ }^{7}$

Islam adalah suatu agama yang berisi suatu ajaran tentang tata cara hidup yang dituangkan Allah kepada umat manusia melalui para Rasulnya sejak dari Nabi Adam sampai kepada Nabi Muhammad Saw. Kalau para Rasul sebelum Nabi Muhammad Saw, pendidikan itu berwujud prinsif atau pokok-pokok ajaran yang disesuaikan menurut keadaaan dan kebutuhan pada waktu itu, bahkan disesuaikan menurut lokasi atau golongan tertentu, maka pada Nabi Muhammad Saw.

5 Sartono Kartodirdjo Pemikiran dan Perkembangan Historiografi Indonesia: Suatu Alternatif (Jakarta: Gramedia, 1982), 10.

6 Sartono Kartodirdjo Pemikiran dan Perkembangan Historiografi Indonesia: Suatu Alternatif (Jakarta: Gramedia, 1982), 7.

7 Akhmad Zulfaidin Akaha, ed, Psikologi Anak dan Remaja Muslim (Jakarta Timur: Pustaka al-Kautsar, 2001), 154-155. 
Prinsip pokok ajaran itu disesuaikan dengan kebutuhan umat manusia secara keseluruhan, yang dapat berlaku pada segala masa dan tempat. Ini berarti bahwa ajaran Islam yang dibawa oleh Rasul merupakan ajaran yang melengkapi atau menyempurnakan ajaran yang dibawa oleh para Nabi sebelumnya. $^{8}$

Pendidikan Islam pada dasarnya merupakan upaya pembinaan dan pengembangan potensi manusia, agar tujuan kehadirannya di dunia ini sebagai hamba Allah Swt dan sekaligus tugas khalifah Allah tercapai sebaik mungkin. Potensi yang dimaksud meliputi potensi jasmaniah dan potensi rohaniah seperti akal, perasaan, kehendak, dan potensi rohani lainnya. Dalam wujudnya, pendidikan Islam dapat menjadi upaya umat secara bersama atau upaya lembaga kemasyarakatan yang memberikan jasa pendidikan bahkan dapat pula menjadi usaha manusia itu sendiri untuk dirinya sendiri. ${ }^{9}$

Pendidikan dalam Islam merupakan bagian dari kegiatan dakwah dan kata terakhir ini yang diungkap di al-Qur'an. Ia memberikan suatu model pembentukan kepribadian seseorang, keluarga dan masyarakat. Sasaran yang hendak dicapai ialah terbentuknya akhlak yang mulia, serta mempunyai ilmu yang tinggi dan taat beribadah. Akhlak yang mulia dimaksud di sini menyangkut aspek pribadi, keluarga dan masyarakat, baik dalam hubungan sesama manusia dan alam lingkungan maupun hubungan dengan Allah pencipta alam semesta (aspek horisontal dan aspek vertikal). Dari sini diharapkan terwujud muslim intelektual $^{10}$ yang pada gilirannya terwujud dalam akhlak alkarimah sebagai wujud manusia Muslim. ${ }^{11}$

${ }^{8}$ Zakiah Daradjat, Metodik Khusus Pengajaran Agama Islam, cet. ke-1 (Jakarta: Bumi Aksara,1995), 59-60.

${ }^{9}$ Abd. Rahman Getteng, Pendidikan Islam dalam Pembangunan (Ujung Pandang: Yayasan al-Ahkam, 1997), 25.

10 Abd. Rahman Getteng, Pendidikan Islam dalam Pembangunan (Ujung Pandang: Yayasan al-Ahkam, 1997), 25, Z. Yusuf, Pendidikan Efektif Agama Islam (Jakarta: IKIP, 1988), 223.

${ }^{11}$ Abd. Rahman Getteng, Pendidikan Islam dalam Pembangunan, (Makassar: Berkah Utami, 1999), 26. 
Landasan yang menjadi fundamen serta sumber dari segala kegiatan pendidikan adalah untuk membentuk pribadi muslim seutuhnya dengan pribadi yang ideal menurut Islam yang meliputi aspek-aspek individual, sosial dan intelektual. Atau dengan kata lain untuk membentuk pribadi muslim yang mampu meraih kebahagiaan dunia dan kebahagiaan akhirat dengan menghambakan diri kepada Allah, memperkuat iman dan melayani masyarakat Islam serta terwujudnya akhlaq yang mulia. $^{12}$

\section{E. Kajian Riset Monodisipliner dan Interdisipliner dalam Pendidikan Islam Menghadapi Isu Nasioal dan Global Wabah Virus Corona}

Corona Menurut Islam Kasus pandemi covid-19 ini dapat dianalisis dengan pendekatan riset monodisipliner, yaitu dengan pendekantan Pendidikan Agama Islam. Menurut Febi Rizki Ramadhan dalam Hidayatullah.com, pandemi virus corona atau popular disebut Covid-19 sedang melanda dunia, tak terkecuali Indonesia. $^{13}$ Majelis Ulama Indonesia (MUI) mengeluarkan larangan salat berjamaah bagi umat Islam di tengah pandemi Covid-19. ${ }^{14}$ Larangan ini termaktub dalam Fatwa Nomor 14 Tahun 2020. Fatwa MUI ini pun selaras dengan pandangan Muhammadiyah, Nahdlatul Ulama, dan Kementerian Agama Republik Indonesia.

Dari sudut pandang sejarah, dalam sejarah perabdaban Islam pada masa kepemimpinan Khalifah Umar bin Khattab ra., ketika wabah penyakit tha'un sedang terjadi sedang terjadi di Syam, Umar bin Khattab melakukan diskusi dengan para sahabat. Amr bin Ash mengeluarkan gagasan mengenai karantina berbasis Kota. Karantina berbasis Kota ini ampuh untuk meredam wabah penyakit tha'un. ${ }^{15}$

12 Abd. Rahman Getteng, Pendidikan Islam dalam Pembangunan, (Makassar: Berkah Utami, 1999), 35.

${ }^{13} \mathrm{Di}$ Indonesia sendiri, terdapat 514 kasus dengan tingkat kematian sebesar 48 orang. Angka ini tentu akan bertambah setiap harinya. Ulama dan kaum Muslimin pun tidak tinggal diam.

${ }^{14} \mathrm{https}: / / \mathrm{www}$. hidayatullah.com.

${ }^{15}$ https://www.hidayatullah.com. 
Islam juga mengajarkan harus berbuat baik pada sesama manusia. Allah Swt berfirman dalam QS. Ali Imran (3): 112:

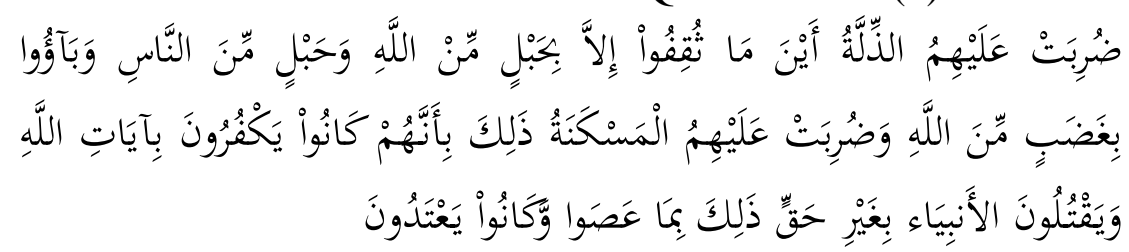

Artinya: "Mereka diliputi kehinaan di mana saja mereka berada, kecuali jika mereka berpegang kepada tali (agama) Allah Swt dan tali (perjanjian) dengan manusia dan mereka kembali mendapat kemurkaan dari Allah Swt dan mereka diliputi kerendahan. Yang demikian itu karena mereka kafir kepada ayatayat Allah Swt dan membunuh Para Nabi tanpa alasan yang benar. Yang demikian itu disebabkan mereka durhaka dan melampaui batas."

Bahwa manusia harus senantiasa berpegang kepada tali Allah dan tali dengan manusia agar tidak diliputi kehinaan di mana saja kita berada. Salah satu bentuk dalam menerapkan nilainilai hablum minannas ialah dengan mencegah terjadinya penyebaran penyakit pada orang lain. Berikutnya, mengingat bahwa Allah Swt memberikan akal dan pikiran bagi manusia, seyogyanya menggunakan akal pikiran sebaik-baiknya agar penularan virus dapat diatasi dan mengambil langkah strategis terkait pencegahan penularan virus corona dengan rutin mencuci tangan, mengurangi aktivitas di luar rumah, dan melakukan isolasi diri ketika sakit merupakan cara yang dapat dilakukan untuk memuliakan dan mengamalkan ajaran Islam dalam kehidupan sehari-hari.

Ibn Katsir ketika menafsirkan QS. al-Baqarah (2): 26, redaksi ayatnya:

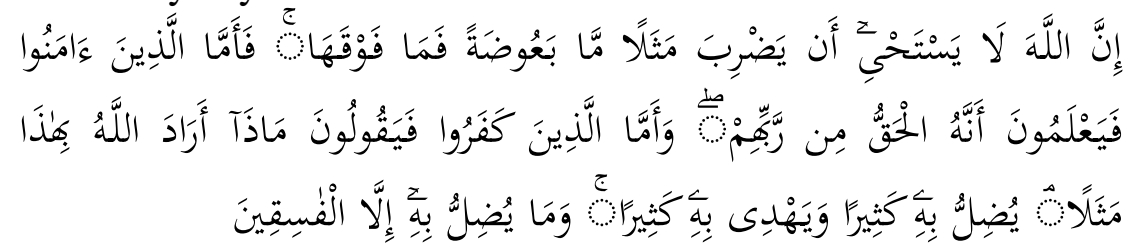


Artinya: "Sesungguhnya Allah tiada segan membuat perumpamaan berupa nyamuk atau yang lebih rendah dari itu. Adapun orang-orang yang beriman, maka mereka yakin bahwa perumpamaan itu benar dari Tuhan mereka, tetapi mereka yang kafir mengatakan: "Apakah maksud Allah menjadikan ini untuk perumpamaan?". Dengan perumpamaan itu banyak orang yang disesatkan Allah, dan dengan perumpamaan itu (pula) banyak orang yang diberi-Nya petunjuk. Dan tidak ada yang disesatkan Allah kecuali orang-orang yang fasik."

Menjelaskan bahwa Allah tidak memandang remeh ciptaan-Nya berupa nyamuk atau lebih kecil lagi. Itu juga berarti bahwa Allah tidak takut untuk membuat perumpamaan apa saja baik dalam bentuk yang kecil maupun besar. Penafrian Ibnu Katsir ini relevan saat ini dengan ditemukan bahwa diameter virus corona diperkirakan mencapai [125] nanometer atau [0,125] mikrometer. Satu mikrometer sama dengan [1000] nanometer. Kecil sekali dan tak mungkin pandangan telanjang manusia mampu melihatnya. Sekalipun sangat kecil dan manusia yang tak mau berpikir meremehkannya, virus ini mampu bertahan lebih dari 10 menit di permukaan, termasuk tangan. Bahkan WHO menyebut virus corona baru (Covid-19) dapat bertahan selama beberapa jam, bahkan beberapa hari. Bahkan dapat bertahan hidup di suhu [26-27] derajat celcius. ${ }^{16}$

Berikutnya, pemahaman Pendidikan Agama Islam tentang Covid-19 dapat dilakukan melaui Riset Intradisipliner yaitu dengan menyajikan hadits yang terkait yaitu Hadis Riwayat Bukhari dan Muslim:

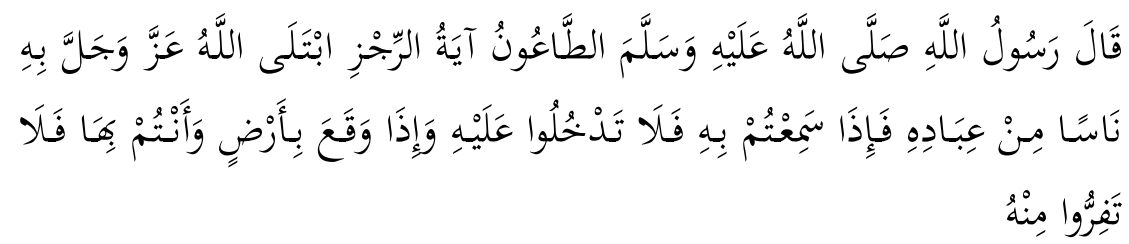

Artinya: "Rasulullah shallallahu 'alaihi wasallam bersabda: "Tha'un (wabah penyakit menular) adalah suatu peringatan dari Allah Subhanahu wa Ta'ala untuk menguji hamba-hamba-Nya dari kalangan manusia. Maka apabila kamu mendengar penyakit itu berjangkit di suatu negeri, janganlah kamu masuk ke negeri itu. ",17

\footnotetext{
${ }^{16}$ https://www.hidayatullah.com.

${ }^{17} \mathrm{https}: / /$ wartakota.tribunnews.com.
} 
Berikunya, pendekatan intradspliner lainnya adalah disiplin ilmu kalam (teologi Islam). Dalam menyikapi pandemi Covid-19 ini, bagi kaum Jabariah yang berideologi fatalis, mereka memandang semua hal yang terjadi pada diri manusia tidak ada sebab sama sekali dari manusia. Karena itu, kata kaum neo-Jabariah, tak perlu takut Corona. "Toh, seperti apa model dan takdir kematianmu telah ditulis di lauh mahfuzh jauh sebelum semesta dicipta." Sementara ayat-ayat yang diajukan kaum Jabariah sebagai argumentasi ajaran teologi mereka, diantaranya QS. as-Saffat (37): 96, redaksinya:

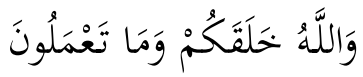

Artinya: "Padahal Allah-lah yang telah menciptakan kalian dan apa yang kalian perbuat itu".

Berbeda Jabariah, kaum Qadariah melihat Tuhan memberikan ruang kebebasan dan kekuatan (qudrah) kepada manusia untuk tidak terinfeksi, melalui ikhtiar dan upaya manusia itu sendiri. Jika kemudian ada manusia terinfeksi, itu bukan disebabkan Tuhan menghendaki demikian, tetapi lebih pada ketidakhati-hatian manusia itu sendiri.

Salah satu argumentasi yang diajukan kaum Qadariah adalah firman Allah Swt yang terkenal dalam QS. ar-Rad (13):11, redaksinya:

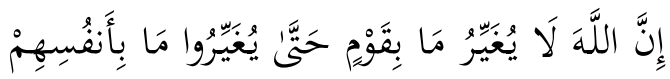

Artinya: "bahwa Allah tidak akan mengubah nasib suatu kaum, hingga mereka mengubah apa yang ada pada diri mereka."

Terlepas dari perdebatan Qadariah dan Jabariah di atas, dalam konteks penanganan virus Corona saat ini, maka semestinya masyarakat memahami bahwa penanganan wabah ini tidak cukup hanya dengan doa dan berpasrah diri (tawakal), tetapi harus ada upaya sungguh-sungguh yang dilakukan untuk menghindari wabah mematikan ini. Taati social distancing, gunakan masker dan hand sanitizer. ${ }^{18}$

${ }^{18}$ http://www.iainpare.ac.id, diakses, tanggal 26 Maret 2020. 
Pemahaman, sikap dan pola perilaku dalam menghadapi isu global pandemi Covid-19 ini, satu bidang keilmuan saja tidak mungkin menjawab persoalan hidup yang sesunggunya bersifat kompleks dan saling berkaitan. Tidak hanya dapat diselesaikan dengan fiqh saja, teologi saja, ekonomi saja, matematika saja dan seterusnya, tetapi membutuhkan penanganan atau pendekatan interdisipliner. ${ }^{19}$

Untuk memahami lebih komprehensif tentang Covid-19, perlu memahaminya dengan kajian virologi yaitu ilmu tentang virus. Menurut ilmu virologi, Penyebab dari wabah ini adalah coronavirus jenis baru yang disebut dengan novel coronavirus 2019 (2019-nCoV). Penyakit ini termasuk dalam golongan virus yang sama dengan virus penyebab severe acute respiratory syndrome (SARS) dan Middle-East respiratory syndrome (MERS).

Sidrotun Naim, seorang ahli di bidang virologi menghimbau agar virus dibendung di Jakarta dan menahan penyebarannya ke daerah lainnya. Ia juga mengingatkan bahwa negara maju saja telah kewalahan menghadapi virus corona tersebut, tidak ada alasan untuk bertindak secara normal. "Tidak ada alasan bagi kita untuk normal operation as usual. Italia, Iran, bahkan Amerika melakukan kesalahan yang jangan kita ulangi, 'mumpung' kita belakangan. Korea kasusnya banyak, tetapi bisa 'menahan' kematian. Atau India," ujarnya dalam surat terbuka tersebut.

Ia juga mengatakan bahwa, Covid-19 bukanlah sebuah candaan, WHO sudah menetapkan sebagai pandemi di mana pertambahan kasus dan angka kematian akan datang cepat atau lambat. Menurutnya, Covid-19 ini bukan hanya berdampak pada kesehatan tapi juga pada ekonomi di dunia. "Saat ini, stabilitas ekonomi bukanlah narasi yang tepat, karena di level global pun sudah jelas sedang tidak stabil. Covid19 combo dengan anjloknya harga minyak," ujarnya.

${ }^{19}$ Saifuddin Mujtaba, "Studi Islam Interdisipliner: Sebuah Keniscayaan", Volume II, Number 2, Juli-September 2015. 
Selain itu, Sidrotun juga menuliskan beberapa langkah yang harus segera dilakukan oleh pemerintah, di antaranya: pertama, pendidikan, bahwa siswa belajar di rumah 14 hari ke depan, boleh jadi perlu lebih, disesuaikan dengan perkembangan; kedua, kesehatan, skrining massif dan aktif dengan cara melakukan tes RT-PCR untuk Covid19 bagi semua ODP agar seseorang dapat dideteksi lebih cepat. Jika positif, bisa diisolasi sehingga tidak bebas berkeliaran dan menjadi penyebar, ketiga, Transportasi Publik. Bekerja di rumah bukan tidak selalu menjadi opsi, namun ada baiknya merubah aturan di dalam kendaraan, keempat, Tempat Ibadah. Seperti yang diketahui tempat ibadah menjadi area dengan kepadatan tertinggi, sehingga diperlukan koordinasi dengan pemimpin dan tokoh agama agar menjadi lebih aman untuk setiap orang yang akan beribadah, kelima, Semua Acara Keramaian Dihentikan untuk Sementara. Cuci tangan dan hindari keramaian memang perlu disampaikan berulang kali kepada masyarakat, pembagian ulang jam kerja. Ada pembagian ulang jam kerja termasuk hari, sehingga tidak terjadi penumpukan. ${ }^{20}$

Selain cabang ilmu Virologi, riset interdisipliner tentang Covid-19 yang sangat relevan adalah bidang ilmu kesehatan. Prof. Dr. dr. Faisal Yunus, Sp.P (K), FCCP yang juga menjabat sebagai Ketua Umum Perhimpunan Dokter Paru Indonesia (PDPI) menjelaskan, ada beberapa treatment atau jenis perawatan yang diberikan kepada pasien COVID-19. Menurutnya, salah satu tindakan suportif yang dilakukan tim medis adalah pemberian obat yang dulunya pernah digunakan untuk menangani wabah penyakit sebelum kemunculan SARS-CoV-2, yaitu Oseltamivir (tamiflu) yakni merupakan jenis obat antiviral yang dipakai dalam pengobatan influenza. Dalam riset berjudul Avian Influenza A(H5N1): Patogenesis, Pencegahan dan Penyebaran pada Manusia, peneliti Maksum Radji menjelaskan bahwa oseltamivir merupakan inhibitor neuraminidase yang gunanya untuk menghentikan replikasi virus. Faisal menjelaskan pula, untuk para pasien COVID-19 yang menderita pneumonia, intervensi medis yang dilakukan ialah dengan memberikan antibiotik. Selain oseltamivir dan antibiotik, pasien COVID-19 juga mengonsumsi vitamin $\mathrm{C}$ dosis tinggi dengan pengawasan dokter.

${ }^{20} \mathrm{https}: / /$ www.pikiran-rakyat.com, diakses tanggal 26 Maret 2020. 
Sementara itu, Juru bicara penanganan virus corona di Indonesia, Achmad Yurianto, memaparkan beberapa gejala klinis dialami para pasien COVID-19 di Indonesia. Gejala awal yang timbul umumnya meliputi demam, batuk dan pilek. Yurianto mengimbuhkan, apabila gejala klinis yang ringan tersebut terlambat ditangani, maka akan berkembang menjadi berat karena pasien mengalami kesulitan bernapas, yakni ditandai dengan munculnya pneumonia. Pneumonia, seperti yang dijelaskan oleh Perhimpunan Dokter Paru Indonesia (PDPI), merupakan infeksi atau peradangan akut di jaringan paru yang disebabkan oleh mikroorganisme, seperti bakteri, virus, parasit, jamur, pajanan bahan kimia, atau kerusakan fisik paru.

Dari situs resmi Lembaga Ilmu Pengetahuan Indonesia (LIPI) diketahui bahwa hepatoprotektor merupakan suatu senyawa obat yang dapat memberikan perlindungan pada hati dari kerusakan yang ditimbulkan oleh racun, obat atau virus.

Berikutnya, pendekatan riset multidisipliner tentang penangan Covid-19 adalah melalui disiplin ilmu farmakologi. Guru Besar Bidang Farmakologi dan Farmasi Klinik Universitas Padjadjaran, Dr. Keri Lestari, M.Si., Apt. menjelaskan bahwa di dunia medis, obat yang sedianya diproduksi untuk menyembuhkan suatu penyakit tertentu, bisa pula digunakan sebagai terapi untuk jenis penyakit lain. Hal itu, menurutnya, sudah jamak dijumpai dan dikenal dengan istilah repurposing drug. Di dunia internasional, penggunaan klorokuin untuk mengatasi Covid-19 mendapat sorotan dari Badan Pengawas Obat dan Makanan AS (Food and Drug Administration/FDA). FDA menyatakan klorokuin belum disetujui untuk mengobati virus corona. Pada akhirnya penggunaan klorokuin secara legal tetap diizinkan apabila pasien virus corona memang menghendakinya. Hanya saja, menurut FDA, belum ada bukti yang mengungkap soal keamanan dan keefektifan klorokuin menangkal coronavirus.

Salah satunya bisa dijumpai dari hasil penelitian terbatas yang digarap oleh peneliti di Prancis terhadap 24 pasien positif COVID-19. Dalam riset klorokuin diklaim dapat mempercepat proses pemulihan. Selanjutnya, hasil riset awal dari Korea Selatan dan China juga menunjukkan efektivitas klorokuin dalam penanganan virus corona Covid-19. Ada pula penelitian diinisiasi oleh Manli Wang, ahli virologi dari Chinese Academy of Sciences. 
Hasil penelitian menunjukkan bahwa klorokuin berhasil menghentikan penyebaran virus corona COVID-19 dalam sel manusia. Sementara hasil sebuah riset yang dipublikasikan dalam Jurnal BioScience Trends menemukan bahwa pemberian klorokuin mampu meredakan pneumonia, meningkatkan fungsi paru, mempercepat konversi negatif infeksi virus, dan mempersingkat waktu gejala infeksi. Studi ini telah dilangsungkan di 10 rumah sakit yang tersebar di beberapa kota di China, termasuk Wuhan, Jingzhou, Guangzhou, Beijing, Shanghai, dan Chongqing.

Selanjutnya, untuk melengkapi kajian literdidipliner pada kasus ini, penting memahami istilah-istilah yang berhubungan dengan COVID-19 berikut:

1. Social distancing.

Menurut Centers for Disease Control and Prevention (CDC), arti istilah 'social distancing' atau 'pembatasan sosial' adalah menghindari tempat umum, menjauhi keramaian, dan menjaga jarak optimal 2 meter dari orang lain. Dengan adanya jarak, penyebaran penyakit ini diharapkan dapat berkurang.

2. Isolasi dan karantina.

Isolasi memisahkan orang yang sudah sakit dengan orang yang tidak sakit untuk mencegah penyebaran virus Corona, sedangkan karantina memisahkan dan membatasi kegiatan orang yang sudah terpapar virus Corona namun belum menunjukkan gejala. Berbagai pakar menganjurkan karantina di rumah dilakukan selama setidaknya 14 hari.

3. Lockdown.

Istilah 'lockdown' berarti karantina wilayah, yaitu pembatasan pergerakan penduduk dalam suatu wilayah, termasuk menutup akses masuk dan keluar wilayah. Penutupan jalur keluar masuk serta pembatasan pergerakan penduduk ini dilakukan untuk mengurangi kontaminasi dan penyebaran penyakit Covid19.

4. Flattening the curve.

'Flattening the curve' atau 'pelandaian kurva' merupakan istilah di bidang epidemiologi untuk upaya memperlambat penyebaran penyakit menular yang dalam hal ini adalah COVID19, sehingga fasilitas kesehatan memiliki sumber daya yang memadai bagi para penderita. Pelandaian kurva ini dapat dilakukan dengan social distancing, karantina, dan isolasi. 
5. Pasien dalam pengawasan (PDP) dan orang dalam pemantauan (ODP) PDP dan ODP

Merupakan definisi yang digunakan untuk mengelompokkan individu berdasarkan: Gejala demam dan/atau gangguan pernapasan, Riwayat perjalanan ke daerah pandemi infeksi virus Corona atau tinggal di daerah tersebut selama 14 hari terakhir sebelum gejala timbul, dan Riwayat kontak dengan orang yang terinfeksi atau diduga terinfeksi COVID-19 dalam 14 hari terakhir sebelum gejala timbul.

6. Herd immunity.

Secara harfiah, istilah 'herd immunity' berarti kekebalan kelompok. Herd immunity terhadap suatu penyakit bisa dicapai dengan pemberian vaksin secara meluas atau bila sudah terbentuk kekebalan alami pada sebagian besar orang dalam suatu kelompok setelah mereka terpapar dan sembuh dari penyakit tersebut.

Beberapa langkah yang bisa dilakukan untuk mencegah infeksi virus Corona, di antaranya: Mencuci tangan dengan benar, Menggunakan masker, Menjaga daya tahan tubuh, Tidak pergi ke negara terjangkit, Menghindari kontak dengan hewan yang berpotensi menularkan coronavirus. ${ }^{21}$

Dalam sudut pandang ilmu ekonomi, Covid-19 bagi Indonesia, Pemerintah Indonesia lebih memprioritaskan dampak terburuk akibat corona ini terhadap pemasukan negara yang mana negara akan kehilangan potensi devisa wisata kurang lebih Rp54,63 triliun. Guna mencegah hal itu, negara segera memberlakukan kebijakan pemotongan harga tiket pesawat sebesar 50 persen untuk beberapa daerah destinasi andalan. Hal ini dikarenakan agar menekan jumlah penurunan wisatawan mancanegara, mengingat wisatawan mancanegaralah yang paling banyak mengunjungi Indonesia untuk berlibur di beberapa daerah seperti Bali, Lombok, Yogyakarta dan kota lainnya. Menurut data dari BPS (Badan Pusat Statistik) menyebutkan bahwa jumlah wisatawan mancanegara yang berkunjung ke Indonesia dari per JanuariOktober 2019 sebanyak 13,62 Juta orang yang berkunjung. Sebagai gantinya wisatawan domestiklah yang menjadi sasaran dari kebijakan ini. Kebijakan ini banyak mendapatkan kritik karena dinilai tidak mementingkan keamanan negara dari wabah virus tersebut.

\footnotetext{
${ }^{21} \mathrm{https}: / / \mathrm{www}$. alodokter.com.
} 
Tetapi, lebih memilih untuk mengamankan pemasukan negara. Dalam pandangan ekonomi islam, kebijakan presiden tersebut berdampak pada ketidakseimbangan dalam sektor ekonomi. Hal ini bertentangan dengan prinsip dasar ekonomi Islam yaitu prinsip tauhid, akhlak dan keseimbangan. ${ }^{22}$

Presiden RI menegaskan bahwa lockdown bukanlah sebuah pilihan, yang terpenting ialah mencegah penyebaran virus itu dengan cara mengurangi mobilitas masyarakat. Ia mengingatkan kepada pemerintah daerah yang mewacanakan lockdown daerahnya, tidak bisa langsung melakukan lockdown tanpa ada koordinasi kepada pemerintah pusat. Kebijakan lockdown hanyalah dari pemerintah pusat. Di pihak lain, beberapa NGO meminta kepada negara agar segera melakukan lockdown seperti Kawalcovid dan Forum Ilmuwan Muda sebelum makin merebaknya virus ini di Nusantara. ${ }^{23}$

Dengan berbagai pertimbangan, Majelis Ulama Indonesia (MUI) membrikan fatwa tentang pelaksanaan ibadah di tengah penyebaran wabah virus corona. Fatwa tersebut menjelaskan tentang langkah yang perlu dilakukan umat muslim di tengah serangan virus tersebut. Fatwa itu dimaksudkan agar masyarakat muslim menghindari penyebaran virus tersebut. Beberapa di antaranya terkait orang yang telah terpapar virus corona wajib menjaga dan mengisolasi diri agar tidak terjadi penularan kepada orang lain. Bagi orang tersebut, shalat jumat apabila laki-laki dapat digantikan dengan salat zuhur di kediamannya. Masyarakat positif corona juga diharamkan untuk melakukan aktifitas ibadah sunnah yang membuka peluang terjadi penularan, seperti jamaah salat lima waktu/rawatib, tarawih, dan Ied di masjid atau menghadiri pengajian maupun tabligh akbar. Selain itu, MUI juga mengatur tentang pelaksanaan ibadah termasuk salat Jumat di wilayah penyebaran wabah virus corona. MUI mengeluarkan fatwa tersebut berdasarkan pendekatan interdisiplin. Setelah mendapatkan informasi yang memadai dari bidang kesehatan, virologi dan sebagainya.

${ }^{22}$ Nandang Ihwanudin, "Hukum Ekonomi Syariah dalam Pentas Ekonomi Global dan Pertumbuhan Ekonomi Dunia", Jurnal Misykat Volume 02 No. 01 $2017,88$.

${ }^{23}$ https://www.suara.com. 


\section{F. Penutup}

Pendidikan agama islam berkaitan dengan isu nasional dan global tentang kasus pandemi Covid-19 menggunakan beberapa disiplin ilmu. Diantara disiplin ilmu tersebut ada beberapa disiplin ilmu yang serumpun sehingga dapat diakui sebagai pendekatan riset intra disipliner, yaitu disiplin ilmu agama islam, hadis, ilmu tafsir, fiqih dan ilmu kalam.

Karena pandemik Covid-19 ini juga berkaitan dengan ilmu kesehatan maka pendekatan penelitian dilakukan menggunakan interdisipliner diantaranya: Firologi, Farmakologi, dan Kesehatan.

Selain itu karena dampaknya tidak hanya pada bidang kesehatan tapi juga pada bidang ekonomi, politik, kebencanaan dan lain lain maka ditinjau pula melalui disiplin ilmu ekonomi dan ilmu pemerintahan.

Bertolak dari pendekatan multidisipliner ini, MUI mengeluarkan Fatwa No.14 tahun 2020 tentang pelarangan salat berjamaah. 


\section{Daftar Pustaka}

Adi, Ida Rochani, "Pendekatan Interdisipliner dalam Studi Amerika," Humaniora, No.7, Januari-Maret 1998.

Akaha, Akhmad Zulfaidin, ed. Psikologi Anak dan Remaja Muslim, Jakarta Timur: Pustaka al-Kautsar, 2001.

Daradjat, Zakiah, Metodik Khusus Pengajaran Agama Islam, cet.ke-1, Jakarta: Bumi Aksara,1995.

Fatwa MUI Nomor 14 tahun 2020.

Getteng, Abd. Rahman, Pendidikan Islam dalam Pembangunan, Ujung Pandang: Yayasan al-Ahkam, 1997.

Ihwanudin, Nandang, "Hukum Ekonomi Syariah dalam Pentas Ekonomi Global dan Pertumbuhan Ekonomi Dunia", Jurnal Misykat Volume 02 No. 01, 2017.

Kartodirdjo, Sartono, Pemikiran dan Perkembangan Historiografi Indonesia: Suatu Alternatif, Jakarta: Gramedia, 1982.

Mujtaba, Saifuddin, "Studi Islam Interdisipliner: Sebuah Keniscayaan", Volume II, Number 2, Juli-September 2015.

Pickering, Michael, (ed.), Research Methods for Cultural Studies, 2008.

Prentice, A.E, "Introduction" dalam Information Science-The Interdisciplinary Context, (ed. J. M. Pemberton dan A.E. Prentice, New York: Neal-Schuman Publishers, 1990.

Tim Pokja Akademik, Kerangka Dasar Keilmuan dan Pengembangan Kurikulum Universitas Islam Negeri (UIN) Sunan Kalijaga Yogyakarta. Yogyakarta: UIN Press, 2006.

Yusuf, Z., Pendidikan Efektif Agama Islam, Jakarta: IKIP, 1988. 